\title{
Transforming the blood glucose meter into a general healthcare meter for in vitro diagnostics in mobile health
}

\author{
Tian Lan ${ }^{\mathrm{a}}$, Jingjing Zhang ${ }^{\mathrm{b}}$ and $\mathrm{Yi} \mathrm{Lu}^{\mathrm{b}}$ \\ ${ }^{a}$ GlucoSentient, Inc. 60 Hazelwood Drive, Champaign IL 61820, USA \\ email: tianlan.1983@gmail.com \\ ${ }^{b}$ Department of Chemistry, University of Illinois at Urbana-Champaign, \\ 601 S. Mathews Ave., Urbana IL 61801, USA \\ email:yi-lu@illinois.edu
}

\begin{abstract}
Recent advances in mobile network and smartphones have provided an enormous opportunity for transforming in vitro diagnostics (IVD) from central labs to home or other points of care (POC). A major challenge to achieving the goal is a long time and high costs associated with developing POC IVD devices in mobile Health (mHealth). Instead of developing a new POC device for every new IVD target, we and others are taking advantage of decades of research, development, engineering and continuous improvement of the blood glucose meter (BGM), including those already integrated with smartphones, and transforming the BGM into a general healthcare meter for POC IVDs of a wide range of biomarkers, therapeutic drugs and other analytical targets. In this review, we summarize methods to transduce and amplify selective binding of targets by antibodies, DNA/RNA aptamers, DNAzyme/ribozymes and protein enzymes into signals such as glucose or NADH that can be measured by commercially available BGM, making it possible to adapt many clinical assays performed in central labs, such as immunoassays, aptamer/DNAzyme assays, molecular diagnostic assays, and enzymatic activity assays onto BGM platform for quantification of non-glucose targets for a wide variety of IVDs in mHealth.
\end{abstract}

Keywords: Blood Glucose Meter, in vitro diagnostics, point of care, immunoassay, aptamer, DNAzyme, molecular diagnostics, enzymatic activity assay, biosensors, mobile health

\section{Introduction}

Coinciding with the rise of the aging population, the prevalence of chronic diseases and the associated healthcare costs has skyrocketed, making it challenging to improve both the quality and the reach of healthcare to those in need. One promising solution is to shift healthcare from hospitals and centralized laboratories to small clinics in the communities and at home or the point of care (POC). To achieve the goals, enormous effort has been made in the past decade to develop technologies that allow rapid patient-provider communications and more convenient diagnostic tests to use by less trained staffs at a lower cost. These efforts have been empowered by today's computational power, fast and reliable networks, and rich software content, with particular impact on POC in vitro diagnostics and mobile health.

Recent advances in mobile technologies have led to significant advances in personal health monitoring and healthcare delivery. For example, many wearable devices, such as wristbands and smartwatch, have been commercialized to monitor an individual's vital signs, 
such as blood pressure, heart rate, and body temperature, and behavior like medication adherence and physical movement (mHealth, 2012). In addition, without needing to be physically at the clinic, communications and consultation with healthcare providers as well as health education can be delivered to anyone with a smartphone or tablet. All the information can be transmitted and stored in the cloud for patients and their caregivers to access and monitor their health status. However, these technologies are mostly limited to delivering information about fitness and healthy state of the users using physical parameters and they miss a critical component of performing diagnostic or screening tests, i.e., using biomarkers inside a human body, which are known to be much more informative and accurate. Furthermore, many therapeutic drugs are known to have narrow therapeutic windows and careful monitoring of the drug levels in the patients regularly at home or other places of POC is critical to successful therapy.

To develop mHealth meters to detect and quantify biomarkers and therapeutic drugs inside a human body, such as those in the blood, urine or saliva, it requires much more advanced technology and thus research and development efforts and funding. Currently, the blood glucose meter (BGM) is the only widely used in vitro diagnostic (IVD) device that has been integrated with mHealth application, either as an attachment to a smartphone (iBGSTAR, 2011) or directly integrating cellular capability (Telcare, 2013). With the growing prevalence of diabetes worldwide, it is not surprising that the BGM is at the forefront of IVDs adapting to the mHealth trend. Decades of research and development, engineering, and marketing efforts have made glucose sensing technology more affordable, accurate, portable, easy to use and low cost to manufacture. In addition, BGM technologies are continuously under development to address needs of the growing population of people with diabetes (Hones et al., 2008). Therefore, instead of developing a brand new platform for IVD tests with mobile devices, leveraging the existing BGM platform to quantify other clinical relevant biomarkers can mitigate risk and lower the costs. Guided by this strategy, we and others have recently transformed unmodified commercially available BGM into a general healthcare meter for IVD in mHealth (Xiang and Lu, 2011, Su et al., 2012, Xiang and Lu, 2012a, Yan et al., 2013, Zhang et al., 2016). In this review, we summarize methods that that have enabled the BGM for quantification of a wide range of targets, such as protein, small organic molecule, metal ion, nucleic acid molecules and enzyme activities.

\section{The Development of Glucose Meter}

The BGM was first introduced around 1970 as a visual and semi-quantitative device where the glucose level was estimated by comparing the color of a glucose-specific reaction on a pad to a printed color chart. Although the first BGMs required multiple steps, large blood volume, and accurate timing, they were still able to assist people with diabetes to manage their glucose levels (Forman et al., 1972). Driven by the need for hundreds of millions of people with diabetes worldwide, the BGM has since evolved from the photometry-based detection used in the 70 s to the current electrochemical-based detection using specific oxidoreductase reactions. The multistep process has been reduced to simply applying a blood droplet onto a strip; the time has reduced from $\sim 2$ min to a mere $\sim 5 \mathrm{~s}$; the volume required to conduct a test has reduced from $25 \mu \mathrm{L}$ to as little as $0.3 \mu \mathrm{L}$; the physical size of the system has shrunk significantly; and the semi-quantitative device has become an 
accurate quantitative system (Heller and Feldman, 2008, Hones et al., 2008). The production cost for the glucose test strips has been lowered by screen printing, while other advanced techniques, such as laser ablation, have also been used for accurately controlling the dimensions of the electrodes (Hones et al., 2008). As a result of decades of research, development, engineering and marketing efforts, the current BGM is a low-cost, portable and accurate device.

Most of the today's BGMs rely on glucose oxidase (GOx) and glucose dehydrogenase $(\mathrm{GDH})$ to generate the glucose-specific electrochemical signal (e.g., electrons). The two enzymes differ in their redox potentials (GOx at $-48 \mathrm{mV}$ versus SHE at $\mathrm{pH} 7.2$ and $\mathrm{GDH}$ at $10.5 \mathrm{mV}$ verse SHE at $\mathrm{pH} 7.0$ ), stability, turnover rates, their affinity and selectivity for glucose (Sato et al., 2001, Kulys et al., 2006, Heller and Feldman, 2008, Yoo and Lee, 2010). Compared with GDH, GOx has a relatively higher selectivity for glucose, and can withstand greater extremes of $\mathrm{pH}$, ionic strength, and temperature. However, the rate of glucose oxidation catalyzed by GOx is $5,000 \mathrm{~s}^{-1}$, compared to the rate of $11,800 \mathrm{~s}^{-1}$ catalyzed by GDH (Heller and Feldman, 2008). In addition, the GOx reaction requires dissolved oxygen as a substrate and thus the lack of oxygen can inhibit enzymatic activity. On the other hand, GHD reaction is oxygen independent, but it is not as glucose specific as GOx (Ferri et al., 2011). Two members of the GDH family (NAD-GDH and FAD-GDH) have been shown to possess both the glucose specificity of GOx and the oxygen independence of GDH (Boguslavsky et al., 1995, Tsujimura et al., 2006) and hence will be more likely to be used in the future.

After the glucose is oxidized, a mediator, such as ferrocene derivatives, hexacyanoferrate, and quinones, is commonly used to transfer the signal from the enzyme to the working electrode. The resulting current can be detected either coulometrically, where the total charge at a fixed time is measured (Heller and Feldman, 2008), or amperometrically, where a predetermined voltage is applied to the working electrode at a fixed time and the corresponding current amplitude is recorded (Hones et al., 2008). The advantage of using mediators is that they have a wide range of redox potentials, are easy to derivatize, have fast electron transfer kinetics, and are stable in both the oxidized and reduced forms. Examples of redox mediators used in commercial glucose test strips are given in Table 1 and an in-depth

Table 1. Mediators used in commercial glucose test strips

\begin{tabular}{|c|c|c|c|c|c|}
\hline Brand & Mediator & Enzyme & $\begin{array}{l}\text { Potential } \\
\text { (vs. } \mathrm{Ag} / \mathrm{AgCl})\end{array}$ & $\begin{array}{l}\text { Bimolecular } \\
\text { rate constant* }\end{array}$ & Reference \\
\hline One Touch Ultra & Ferricyanide & GOx/GDH & $300 \mathrm{mV}$ & $13.6 \mathrm{M}^{-1} \mathrm{~s}^{-1}$ & $\begin{array}{l}\text { Lee et al., 2015; } \\
\text { Uemastu et al., } 2012\end{array}$ \\
\hline Arkray & $\begin{array}{l}\text { Ruthenium } \\
\text { Hexamine }\end{array}$ & GDH & $\begin{array}{l}-200 \mathrm{mV} \\
\text { (vs. SCE) }\end{array}$ & $80 \mathrm{M}^{-1} \mathrm{~s}^{-1}$ & Morris et al., 1992 \\
\hline FreeStyle & $\begin{array}{l}\mathrm{Os}^{2+/ 3+} \\
\text { Complex }\end{array}$ & GDH & $-160 \mathrm{mV}$ & N. A. & $\begin{array}{l}\text { Heller and Feldman, } \\
2010\end{array}$ \\
\hline Precision Xtra & $\begin{array}{l}\text { Phenanthroline } \\
\text { quinone** }\end{array}$ & GDH & $200 \mathrm{mV}$ & N. A. & $\begin{array}{l}\text { Cardosi and Liu, } \\
2012\end{array}$ \\
\hline Precision QID & Ferrocene*** & GOx & $600 \mathrm{mV}$ & $4.3 \times 10^{5} \mathrm{M}^{-1} \mathrm{~s}^{-1}$ & Cunningham, 2016 \\
\hline \multicolumn{6}{|c|}{$\begin{array}{l}\text { * Electron transfer rate between the mediator and the respective enzyme } * * 1,10 \text {-phenanthroline quinone; } * * * \\
1,1^{\prime} \text {-dimethyl-3-(2-amino-1-hydroxyethyl) ferrocene }\end{array}$} \\
\hline
\end{tabular}


review of properties of these mediators can be found elsewhere (Ryabov, 2004).

Despite the commercial success of today's mediator based BGM systems, certain drugs, metabolites and other molecules in the blood have been shown to interfere with these mediators-based glucose sensors (Tang et al., 2000). For instance, acetaminophen is one of the most common drugs associated with both accidental and intentional poisoning and a high dose of acetaminophen can interfere with electrochemical biosensors, by directly generating a current on the working electrode (Cartier et al., 1998). Some GDH-based BGM (PQQ-GDH) are more susceptible to non-glucose sugars, such as maltose and galactose, or other chemicals used for medical treatments, such as icodextrin, as these molecules can be recognized by GDH and thus can cause falsely high level of signals (Janssen et al., 1998, FDA, 2009, Ferri et al., 2011). Use of other members of the GDH family, including NAD-GDH and FAD-GDH, can overcome the specificity issues with PQQ-GDH (Boguslavsky et al., 1995, Tsujimura et al., 2006).

Another way to address the above interference issues is to develop a new generation of glucose biosensors based on direct electron transfer (DET) from the enzyme active site to the electrode. With DET, only a low potential is required, leading to a very low interference. However, DET between GOx or GDH and electrode surface can be very slow due to the protein shell shielding the enzyme active site (Bankar et al., 2009). The efficiency of DET depends not only on the distance between the active site of the enzyme and the electrode but also on the properties of the electrode material and on the immobilization technique (Tellechea et al., 2012, Ludwig et al., 2013). For the limited number of GOx and GDH that are capable of DET, the efficient electron transfer still requires conformational change of the enzyme, which may result in an obvious loss of activity (Felice et al., 2013, Seehuber and Dahint, 2013). An appropriate balance between the enzymatic and electrochemical activities is vital for DET glucose biosensors, and more innovation is still necessary to reach that balance and a commercially viable product. Various attempts to overcome the long electron-tunneling distance were made to demonstrate the feasibility of a DET glucose sensor (Liang et al., 2015, Terse-Thakoor et al., 2015, Zhang et al., 2015c, Zhou et al., 2015, Blaik et al., 2016). In these reports, the improved sensing performance by the direct electron transfer has been realized by incorporating the enzyme with nanomaterials, which play an important role in the enzyme immobilization, owing to nanomaterial's highly specific surface area, good biocompatibility, stability, and facilitating electron transfer (Willner et al., 2006). The new generation of the glucose sensor is expected to be globally realized through effectively connecting the redox active center of the enzyme to the electrode by using nanomaterials as "conducting wires".

Today's BGM systems are sufficient for monitoring glucose levels in people with diabetes. As required by the ISO standard, $95 \%$ of the measured glucose values must be within \pm 15 $\mathrm{mg} / \mathrm{dL}(0.83 \mathrm{mM})$ of reference measurement at glucose concentration $<100 \mathrm{mg} / \mathrm{dL}(5.6 \mathrm{mM})$ or within $\pm 15 \%$ at glucose concentration $\geq 100 \mathrm{mg} / \mathrm{dL}$ (ISO, ISO 15197:2013). The U.S. FDA has drafted stricter requirements where $95 \%$ of all measurements within the working range of the BGM should be within $\pm 15 \%$ of reference measurement and $99 \%$ of all measurements within $20 \%$ of the reference (FDA, 2014). The detection range of commercial BGMs commonly extends from $10 \mathrm{mg} / \mathrm{dL}$ to $600 \mathrm{mg} / \mathrm{dL}(\sim 0.56-33 \mathrm{mM})$, which cover the dynamic range of glucose in people with diabetes well. Considering the number of factors 
that will impact the glucose measurement, such as extreme hematocrit, temperature, altitude, and user error, the current BGM system has overcome significant hurdles and become today's most widely used portable IVD device in the world (Tonyushkina and Nichols, 2009).

\section{Design of the BGM-based biosensors for IVDs of non-glucose targets}

\subsection{Components of the BGM-based IVDs for non-glucose targets}

A biosensor typically includes three main components as illustrated in Figure 1: the target recognition element, the signal transduction and amplification method, and the signal readout modality. However, as noted above, traditional BGMs are designed to recognize glucose specifically so people with diabetes can monitor their glucose levels accurately. A major challenge in using a BGM as a general portable meter for targets beyond glucose is finding a general method can link the concentration of non-glucose target to that of glucose while avoiding major changes to design and manufacturing processes. As such, the target recognition element plays a key role in transforming commercially available BGMs that can detect only glucose into a general healthcare meter to detect many non-glucose targets. The signal transduction and amplification method have major influence on the sensitivity of the

\section{Use of Blood Glucose Meter (BGM) for quantification of non-glucose targets}

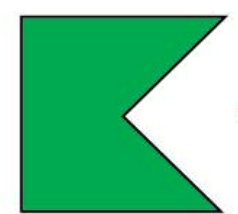

Target

Protein

Small molecules

Nucleic Acids

Metal ions

Enzyme activity

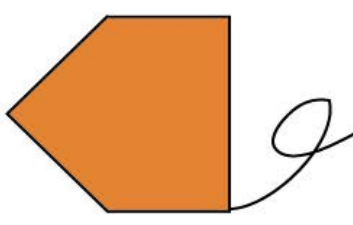

Recognition

Antibody

Aptamers

Nucleic Acids

DNAzyme

Enzyme substrates
Signal tranduction

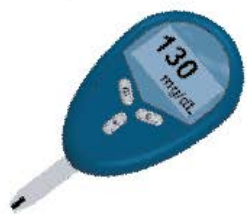

\& amplification BGM quantification

Invertase Glucose

Glucoamylase NADH

Nanocontainers

Other enzymes

Figure 1. Different approaches using BGMs for quantification of non-glucose targets.

BGM as it translates the specific recognition of the analyte into quantifiable signals. In the sections below, we will first summarize recent innovations in signal transduction and amplification, including their integration with nanotechnology, and then discuss the implementation of various recognition elements, including antibodies, DNAs, and enzymes into BGM-based biosensors for IVDs for a wide range of non-glucose targets.

\subsection{Signal transduction and amplification strategies for BGM-based IVDs for non-glucose targets}

Signal transduction and amplification are necessary to employ current BGMs for quantification because most non-glucose targets have much lower concentrations in blood or other body fluids, which of often in micromolar or lower than that of glucose in the blood, which is in the milimolar range. To achieve the goal, three main approaches have demonstrated the use of BGM for detecting non-glucose targets, including 1) enzyme-mediated glucose generation, 2) target responsive release of encapsulated glucose and 3) generation of non-glucose molecules that can also be detected by BGM, such as 
nicotinamide adenine dinucleotide (NADH).

\subsubsection{Glucose-generating enzymes}

The first assay based on an unmodified BGM for non-glucose targets was reported by the Lu group in 2011 (Xiang and Lu, 2011). In this approach, invertase was used to transduce the recognition event to a quantifiable glucose signal by hydrolysis of sucrose that does not register any reading on BGM into glucose that can be measured by BGM. With high catalytic activity in a wide range of temperature and $\mathrm{pH}$ (Chavez et al., 1997, Belcarz et al., 2002), the invertase serves not only for signal transduction from binding non-glucose targets into glucose signals, but also provides the necessary signal amplification through enzymatic turnovers, since most of the analyte are present in concentrations much below the working range of BGM and the enzymatic turnovers can amplify a low concentration of targets (picomolar or below) into high concentrations (in millimolar) of glucose. Yeast invertase has been used most frequently to develop BGM assays due to their high enzymatic activity $\left(k_{\mathrm{cat}}=\right.$ $1540 \mathrm{~s}^{-1}$ and $k_{\text {cat }} / K_{\mathrm{m}}=7390$ at optimal condition), heat stability (active up to $80{ }^{\circ} \mathrm{C}$, optimal between $\left.60-75{ }^{\circ} \mathrm{C}\right)$, wide $\mathrm{pH}$ tolerance $(\mathrm{pH} 3-6$, optimal at $\mathrm{pH} 5.5)$ and substrate specificity (sucrose, $K_{\mathrm{m}}=12.5 \mathrm{mM}$; and raffinose normally found in plants, $K_{\mathrm{m}}=150$ mM)(Chavez et al., 1997, Gangadhara et al., 2008).

Besides invertase, glucoamylase ( $\gamma$-amylase, from Aspergillus niger) is another enzyme reported that has been employed in BGM-based biosensors (Yan et al., 2013). Used commonly in starch processing industry to generate glucose from corn syrups, glucoamylase generates glucose by cleaving the last $1-4-\alpha$-glycosidic bonds at the non-reducing end of amylopectin and the $\alpha-1-6$-glycosidic bond (Wong, 1995). Compared to invertase, glucoamylase has a much lower $k_{\text {cat }} \sim 49 \mathrm{~s}^{-1}\left(k_{\mathrm{cat}} / K_{\mathrm{m}}=450\right.$ for maltohexaose) and less substrate specificity, where many other sugars, such as amylose, amylopectin, dextrin, maltose, and glycogen, can be recognized. The glucoamylase is also less tolerant to elevated temperature and acidic $\mathrm{pH}$, where the enzyme can be rapidly deactivated $\left(>70{ }^{\circ} \mathrm{C}\right.$ or $\left.<\mathrm{pH} 4\right)$ (Sauer et al., 2000, Kumar and Satyanarayana, 2009).

Other enzymes, such as penicillin-G-amidase (PGA), and esterase (Mohapatra and Phillips, 2013) and alkaline phosphatase (ALP) (Zhang et al., 2015b), have also been reported in BGM-based biosensors. The use of PGA and esterase require synthetic substrates and the enzymes will recognize all of the natural substrate, such as penicillin and esters; hence, they are used much less frequent for assay development. The ALP has been used as a reporter enzyme in ELISA, but it has a relatively broad substrate specificity (Millan, 2006). All these signaling enzymes described above can be linked to different recognition modules to develop a wide variety of assays using BGM for quantification.

\subsubsection{Encapsulated glucose}

Instead of using enzymes to generate glucose, an alternative strategy to provide the necessary link between target recognition and glucose levels is to directly release encapsulated glucose from nanocontainers, such as mesoporous silica (Fu et al., 2013, Gao et al., 2014, Hou et al., 2014, Tang et al., 2014, Wang et al., 2014b) and liposome (Zhao et al., 2015b), in response to a target recognition event. Gao and co-workers (Gao et al., 2014) reported the use of magnetic mesoporous particles as glucose nanocontainers, gated by 
antibody-mediated target responsive poly(ethyleneimine)-coated polystyrene microsphere (PEI-PSMS). In the absence of target, the pores on nanocontainers are closed by PEI-PSMS through electrostatic interaction between the cationic PEI copolymer and the negatively charged antibody. In the presence of the target, such as brevetoxin B, on the other hand, binding of the target to the antibody triggers the release of the gating polystyrene microspheres, releasing the glucose molecule inside the magnetic nanocontainer. Similar mesoporous materials have also been used with different gating approaches, including antibody-, DNAzyme-, aptamer-, and telomeric DNA-conjugated gold nanoparticles (AuNPs) for BMG-based detection of toxins (Gao et al., 2014, Tang et al., 2014), $\mathrm{Pb}^{2+}$ (Fu et al., 2013), cocaine and telomerase activity (Wang et al., 2014b). Instead of using the mesoporous material, Lin and co-workers demonstrated the use of glucose encapsulated liposome to link the detection of released glucose with a BGM to the quantification of target biomarkers (Zhao et al., 2015b). In this approach, glucose encapsulated liposome was functionalized with the antibody. An antibody-antigen sandwich formed between the liposome, target antigen, and a secondary antibody coated magnetic particle was separated by a magnet. Treating the isolated liposome with detergent released the encapsulated glucose in proportion to target concentration, which can be quantified by a BGM. The properties of the various nanocontainers are summarized in Table 2.

Table 2. Physical properties of various nanocontainers to encapsulated glucose for BGM assays.

\begin{tabular}{|c|c|c|c|c|c|c|}
\hline \multicolumn{4}{|c|}{ Glucose container } & \multirow[t]{2}{*}{ Gating material } & \multirow[t]{2}{*}{ Target } & \multirow[t]{2}{*}{ Reference } \\
\hline Type & Size & Pore size & Volume* & & & \\
\hline MSN & $100 \mathrm{~nm}$ & $2.2 \mathrm{~nm}$ & N.P. & DNAzyme & $\mathrm{Pb}^{2+}$ & Fu et al., 2013 \\
\hline MMN & N.P. & $12.3 \mathrm{~nm}$ & $0.52 \mathrm{~cm}^{3} / \mathrm{g}$ & $\mathrm{Ab} / \mathrm{PEI}-\mathrm{PSMS}$ & Brevetoxin B & Gao et al., 2014 \\
\hline MSN & $120 \mathrm{~nm}$ & $3.2 \mathrm{~nm}$ & $0.42 \mathrm{~cm}^{3} / \mathrm{g}$ & Aptamer/AuNP & ATP, cocaine & Hou et al., 2014 \\
\hline MSN & $200 \mathrm{~nm}$ & $4.4 \mathrm{~nm}$ & N.P. & Telomeric DNA & Telomerase & Wang et al., 2014b \\
\hline MSN & $180 \mathrm{~nm}$ & $2.3 \mathrm{~nm}$ & N. P. & Antibody/AuNP & Aflatoxin B1 & Tang et al., 2014 \\
\hline Liposome & $176 \mathrm{~nm}$ & N. A. & $2.53 \mathrm{aL}$ & N.A. & phospho-p53 & Zhao et al., $2015 b$ \\
\hline \multicolumn{7}{|c|}{$\begin{array}{l}\text { MSN: Mesoporous silica nanosphere; MES: magnetic mesoporous nanostructure; AuNP: Gold nanoparticle; } \\
\text { Ab: antibody; ATP: adenosine triphosphate; N.A.: Not applied; N.P.: Not provided. } \\
\text { *Pore volume for MSN and single liposome }\end{array}$} \\
\hline
\end{tabular}

\subsubsection{NADH-generating enzymes}

A recent discovery has demonstrated the commercially available BGM can be directly used to quantitate NADH, a natural coenzyme widely used in enzymatic reactions, which further expands the BGM's capability to quantitate enzymatic activities or metabolite levels through measuring NADH levels (Zhang et al., 2016). Lu and coworkers have demonstrated the quantification of lactate by employing a set of an enzymatic reaction that consumes $\mathrm{NADH}$ in proportional to lactate present and directly detecting the NADH consumption using a commercial BGM. The assay demonstrated a comparable performance to clinical methods (YSI lactate analyzer) in patient samples. The limit of detection (LoD) was $0.034 \mathrm{mM}$ with adjustable ranges between 0.034 to $2.5 \mathrm{mM}$ and to $25 \mathrm{mM}$. The same approach can be applied to detect not only other metabolites, such as lactate but also the enzymatic activity of glucose-6-phosphate dehydrogenase (G6PD) by measuring the decrease of NADH levels in 
the presence of the enzyme. The LoD for G6PD was determined to be $0.10 \mathrm{U} / \mathrm{mL}$ from spiked human blood samples. The dynamic range of the G6PD assay is between $0.10-4 \mathrm{U} / \mathrm{mL}$. Before this work, a similar approach was reported, but it requires a customized test strips to function with a commercial BGM (Nie et al., 2010).

\subsection{Target-recognition elements for BGM-based IVDs for non-glucose targets}

In addition to signal generation and amplification, target recognition is also a critical component in BGM-based biosensors as it determines the selectivity of the biosensor. Targets of interests can present intracellularly or extracellularly, but regardless of the sampling matrix, the target must be recognized in complex sample matrices such as blood. In addition, the targets themselves can be as complex as a whole cell or as simple as a metal ion, which would require different recognition strategy. In this section, we will provide an overview of molecular recognition elements, including antibodies, DNA/RNA aptamers, DNAzymes, protein enzymes and other molecules that have been employed in BGM-based biosensors.

\subsubsection{Employing Antibodies as target recognition elements in BGM-based IVDs}

\section{A. Sandwich immunoasay}

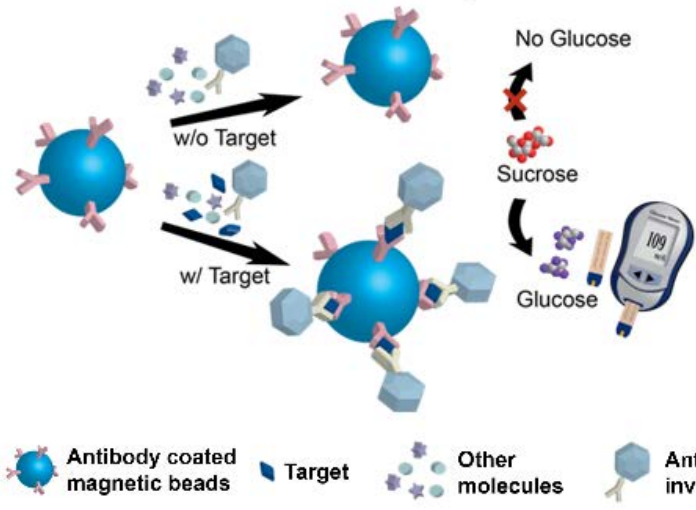

B. Competitive immunoasay

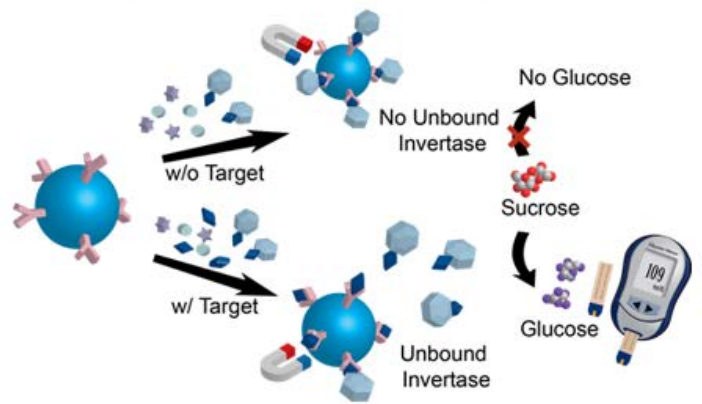

Figure 2. Designs for BGM based immunoassays, in both the sandwich (A) and competitive (B) formats. (Xiang and $\mathrm{Lu}, 2012 \mathrm{a}$ ).

Since its discovery, the antibody has been recognized for its high affinity and selectivity and has severed as the backbone of modern medical testing being used in various immunoassays from complex radioimmunoassays, to high throughput bead-based enzyme immunoassays, and to the highly convenient chromatographic immunoassays (or the dipstick tests). With decades of research and development in both academia and industry, antibodies are now available for an extensive range of targets with excellent affinity and selectivity (Morgan et al., 1996). Advantages of antibody-based recognition elements include high selectivity and high affinity toward the targets and wide availability after decades of research and development (Giri et al., Shriver-Lake et al., 1997, Hall, 2002, Smith et al., 2011). As a result, most clinical assays, both in centralized labs and at POC, use antibodies. Therefore, developing general methods of transforming of these antibody-based assays onto the BGM platform can have a huge impact on POC IVDs and mHealth.

In most BGM-based immunoassays, antibodies are used in either the sandwich or competitive assay format to capture or release enzyme labels for quantitative detection of 
targets. In the sandwich assay format, the target present in the sample binds to both the primary antibody, which is conjugated to either micro-beads or micro-plates and the secondary antibody, which is then conjugated signal transduction and amplification enzymes described in section 3.2 (e.g. invertase, glucoamylase) to form the sandwich complex (Figure 2A). After washing away those components that do not bind to the micro-beads or micro-plates, the enzyme contained in the sandwich complex can be used to generate glucose and establish a direct correlation between the concentration of the target and the glucose monitored by a BGM. Using the sandwich format, a number of sensitive and selective BGM-based immunoassays have been developed for the detection of streptavidin and prostate-specific antigen (PSA) (Xiang and Lu, 2012a), insulin and glycated hemoglobin (HbA1c) (Xiang et al., 2014), alpha-fetoprotein (AFP) (Wu et al., 2015), carcinoembryonic antigen (CEA) (Su et al., 2012), phosphorylated p53 (on Serine 15, phospho-p53) (Zhao et al., 2015b), neuron-specific enolase (NSE) (Fu et al., 2014, Fu et al., 2015), albumin (Zhao et al., 2015a), and Salmonella (Joo et al., 2013). In some cases, additional signal amplification was provided by using nanomaterials, such as gold nanoparticles and nanoflowers (Fu et al., 2014, $\mathrm{Fu}$ et al., 2015), dendritic polyaniline nanofiber (DPANF) (Wu et al., 2015), and graphene-oxide-gold nanocomposite (Zhao et al., 2015a), to increase enzyme loading and hence higher sensitivity.

While sandwich assay format can be highly sensitive and specific, it requires the target to have multiple antibody binding sites, and as a result, it's not feasible for targets, such as small molecules, with a single antibody binding site (epitope). For the detection of these targets with a single epitope, a competitive assay design has been employed in which the target competes with its analog that has been conjugated to signal transduction and amplification enzymes described in section 3.2 (e.g. invertase) for binding the primary antibody conjugated to the micro-beads. The more targets present in a sample, the more invertase will be present in the solution, resulting higher glucose signal in the solution (Figure 2B). Using this design, a BGM-based biosensor for small molecular Ochratoxin A (OTA) was developed with high sensitivity and specificity (Xiang and Lu, 2012a). In another design, Tang and co-workers applied a one-step competitive displacement strategy to BGM-based sensors for sensitive monitoring of glucose (cargo) release in response to brevetoxin B (Gao et al., 2014) and aflatoxin $\mathrm{B}_{1}$ (Tang et al., 2014). The detailed performance of these BGM based immunoassays is summarized in Table 3.

Table 3. Performances of BGM based immunoassays

\begin{tabular}{|c|c|c|c|c|c|c|}
\hline & LoD & $\begin{array}{l}\text { Assay } \\
\text { time }\end{array}$ & Range & $\begin{array}{l}\text { Sample } \\
\text { Matrix }\end{array}$ & $\begin{array}{l}\text { Nanomaterial } \\
\text { Amplification }\end{array}$ & Reference \\
\hline Sandwich & & & & & & \\
\hline PSA & $1.5 \mathrm{ng} / \mathrm{mL}$ & $\sim 10 \mathrm{~h}$ & $\begin{array}{l}1.5-100 \\
\mathrm{ng} / \mathrm{mL}\end{array}$ & Serum & No & $\begin{array}{l}\text { Xiang and } \mathrm{Lu} \text {, } \\
2012 \mathrm{a}\end{array}$ \\
\hline CEA & $1.0 \mathrm{ng} / \mathrm{mL}$ & $\sim 2.5 \mathrm{~h}$ & $\begin{array}{l}1.0-50 \\
\mathrm{ng} / \mathrm{mL}\end{array}$ & Serum & No & Su et al., 2012 \\
\hline Salmonella & $10 \mathrm{cfu} / \mathrm{mL}$ & $\sim 1 \mathrm{~h}^{*}$ & $\begin{array}{l}10-10^{6} \\
\mathrm{cfu} / \mathrm{mL}\end{array}$ & Milk & No & Joo et al., 2013 \\
\hline
\end{tabular}




\begin{tabular}{|c|c|c|c|c|c|c|}
\hline Insulin & $1 \mathrm{nM}$ & $\sim 3$ days & $1-10 \mathrm{nM}$ & Buffer & No & Xiang et al., 2014 \\
\hline $\mathrm{HbA1c}$ & $3 \mathrm{mg} / \mathrm{L}$ & $\sim 4 \mathrm{~h}$ & $\begin{array}{l}3-200 \\
\mathrm{mg} / \mathrm{L}\end{array}$ & Buffer & No & Xiang et al., 2014 \\
\hline NSE & $\begin{array}{l}0.05 \\
\mathrm{ng} / \mathrm{mL}\end{array}$ & $\sim 4 \mathrm{~h}$ & $\begin{array}{l}0.05-50 \\
\mathrm{ng} / \mathrm{mL}\end{array}$ & Serum & $\begin{array}{l}\text { Yes } \\
\text { AuNP/AuNF }\end{array}$ & $\begin{array}{l}\text { Fu et al., 2014, } \\
2015\end{array}$ \\
\hline AFP & $\begin{array}{l}0.03 \\
\mathrm{ng} / \mathrm{mL}\end{array}$ & $\sim 3 \mathrm{~h}$ & $\begin{array}{l}0.1-50 \\
\mathrm{ng} / \mathrm{mL}\end{array}$ & Serum & $\begin{array}{l}\text { Yes } \\
\text { DPANF }\end{array}$ & Wu et al., 2015 \\
\hline Phospho-p53 & $50 \mathrm{pg} / \mathrm{mL}$ & $\sim 3 \mathrm{~h}$ & $\begin{array}{l}0.1-100 \\
\mathrm{ng} / \mathrm{mL}\end{array}$ & Plasma & No & Zhao et al., 2015b \\
\hline Albumin & $0.5 \mathrm{ng} / \mathrm{mL}$ & $\sim 3 \mathrm{~h}$ & $\begin{array}{l}0.001-10 \\
\mu \mathrm{g} / \mathrm{mL}\end{array}$ & Cell media & $\begin{array}{l}\text { Yes } \\
\text { GO-Au }\end{array}$ & Zhao et al., $2015 \mathrm{a}$ \\
\hline \multicolumn{7}{|l|}{ Competitive } \\
\hline OTA & $17 \mathrm{nM}$ & $\sim 3 \mathrm{~h}$ & $\begin{array}{l}17-1000 \\
\mathrm{nM}\end{array}$ & Serum & No & $\begin{array}{l}\text { Xiang and Lu, } \\
2012 \mathrm{a}\end{array}$ \\
\hline Brevetoxin B & $\begin{array}{l}0.01 \\
\mathrm{ng} / \mathrm{mL}\end{array}$ & $25 \mathrm{~min}$ & $\begin{array}{l}0.01-20 \\
\mathrm{ng} / \mathrm{mL}\end{array}$ & Seafood & No & Gao et al., 2014 \\
\hline Aflatoxin B1 & $5 \mathrm{ng} / \mathrm{kg}$ & $20 \mathrm{~min}$ & $\begin{array}{l}0.01-15 \\
\mu \mathrm{g} / \mathrm{kg}\end{array}$ & Peanut & No & Tang et al., 2014 \\
\hline
\end{tabular}

LoD: limit of detection; PSA: prostate specific antigen; CEA: carcinoembryonic antigen; HbA1c: hemoglobin A1c; NSE: neuron-specific enolase; AFP: alpha-fetoprotein; OTA: Ochratoxin A; cfu: colony forming unit; AuNP: gold nanoparticle; AuNF: gold nanoflower; DPANF: dendritic polyaniline nanofiber; GO-Au: graphene oxide gold nanocomposite;

* Glucose production by invertase carried out at $40{ }^{\circ} \mathrm{C}$

\subsubsection{Employing Aptamers and DNAzymes as target-recognition elements in BGM-based IVDs}

While antibodies possess a number of desirable properties for IVDs as discussed in the above section, they are quite expensive to produce and not very stable at room temperature. Once denatured during either manufacturing process or storage, it is almost impossible to renature the antibodies to regain its full function. These properties making it difficult for antibodies to be applied for affordable POC IVDs. In addition, the quality of many antibodies varies widely from one batch to another. Finally, antibodies are not very good at recognizing small molecular targets such as metal ions and small organic molecules.

With similar properties to antibodies and enzymes, DNA/RNA aptamers and DNAzymes/ribozymes are nucleic acid molecules with distinct advantages in medical diagnostics. Isolated with an in vitro process called Systematic Evolution of Ligand by EXponential enrichment, or SELEX (Ellington and Szostak, 1990, Tuerk and Gold, 1990, Beaudry and Joyce, 1992, Ellington and Szostak, 1992, Breaker et al., 1994), DNA/RNA aptamers and DNAzymes/ribozymes can be isolated to bind to a wide range of targets with high affinity and specificity, including metal ions, small molecules, protein and even virus or whole cell, making them one of the most versatile recognition elements (Lu and Liu, 2006, Navani and Li, 2006, Shangguan et al., 2006, Mok and Li, 2008, Li and Lu, 2009, Liu et al., 2009, Wu et al., 2010, Sai Lau and Li, 2011, Zhang et al., 2011, Ali et al., 2012, Torabi and Lu, 2014, Xiang and Lu, 2014, Shen et al., 2015). In addition to target-binding capability, 
DNAzymes can catalyze chemical reactions, the most common being hydrolysis of a phosphodiester bond (Breaker et al., 1994, Carmi et al., 1996, Santoro and Joyce, 1997, Carmi et al., 1998, Santoro and Joyce, 1998, Li et al., 2000, Carmi and Breaker, 2001, Brown et al., 2003, Liu et al., 2007, Brown et al., 2009, Torabi et al., 2015). Compared to antibodies, aptamers and DNAzymes have distinct advantages originating from their nucleic acid properties: 1) they can be synthesized in the test tubes at a much lower cost that that of antibodies; 2) they can be readily conjugated to many signal transducing elements, such as fluorophores, nanomaterials and enzymes at an exact location; 3) they are more stable than antibodies at room temperature and during storage; 4) unlike antibodies, they can be denatured during manufacturing process and storage and can regain binding or catalytic activity after renaturation at physiological condition before sensing applications; 5) since the DNA and RNA can be synthesized chemically, they have minimal batch-to-batch variations, and 6) they have been shown to bind small molecules such as metal ions much more selectively than those of antibodies. These properties make them excellent molecular recognition elements in developing BGM-based biosensors to quantify a variety of analytical targets, such as cocaine (Xiang and Lu, 2011, Yan et al., 2013, Hou et al., 2014, Zhou et al., 2014b), adenosine (Xiang and Lu, 2011, Liu et al., 2012), ATP (Yan et al., 2013, Hou et al., 2014), dopamine (Hun et al., 2015b), melamine (Gu et al., 2015), myoglobin (Wang et al., 2015a), platelet-derived growth factor-BB (PDGF-BB) (Ma et al., 2014), interferon-gamma (Xiang and Lu, 2011, Lan et al., 2015), uranium ( $\mathrm{UO}_{2}{ }^{2+}$ ) (Xiang and $\mathrm{Lu}, 2011,2013$ ), and lead $\left(\mathrm{Pb}^{2+}\right)$ (Fu et al., 2013, Xiang and Lu, 2013, Liao and Li, 2014, Zhang et al., 2015a).

The general design of an aptamer-based BGM-sensor involves a DNA-conjugated invertase complex that can be hybridized with an aptamer. The binding of the target by the aptamer weakens the hybridization and triggers the release of the DNA-conjugated invertase, which can be used for glucose production (Figure 3). For instance, by using the structure-switching SELEX method (Nutiu and Li, 2003, 2004, 2005), a melamine responsive

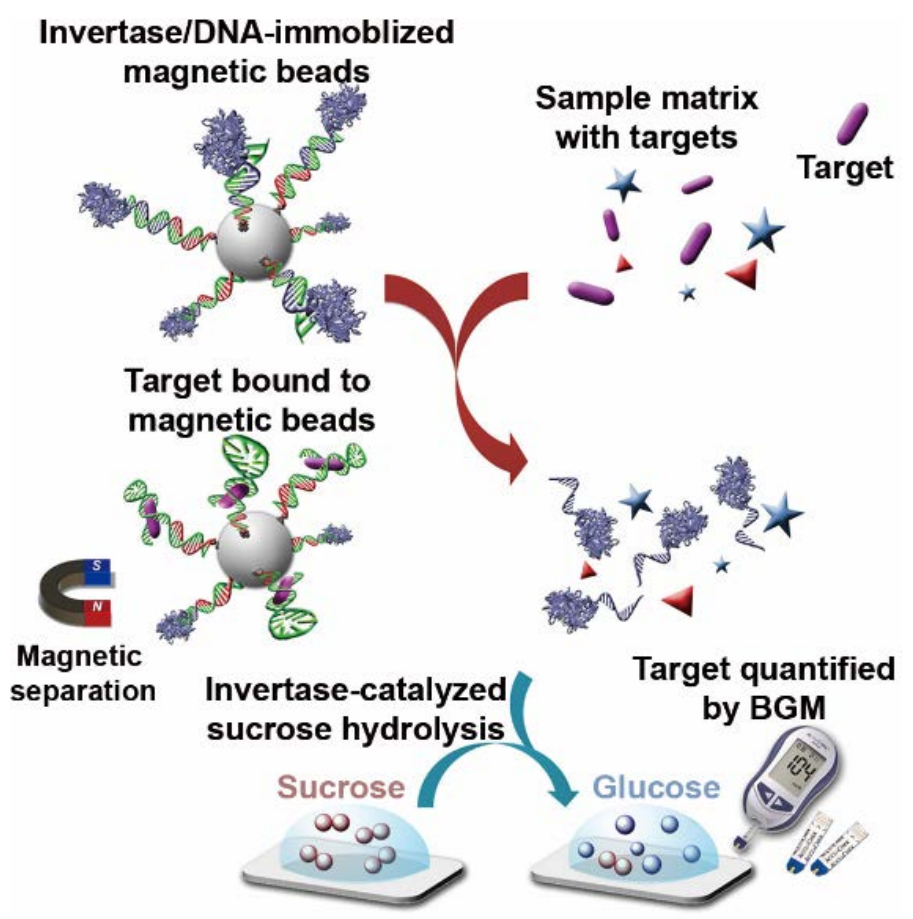

Figure 3. The design of the first BGM based assay using aptamers and DNAzymes. (Xiang and Lu, 2011) 
aptamer was selected and then converted to a BGM-based melamine sensor with the assistance of invertase-conjugated DNA (Gu et al., 2015). In addition, the use of purified DNA-invertase conjugates from reaction mixture via a biotin-desthiobiotin displacement strategy was demonstrated to further improve the analytical performance of BGM-based sensors (Zhou et al., 2014b). More interestingly, instead of an in-solution binding and release strategy adopted in previous examples, Yang and co-workers demonstrated that an aptamer cross-linked and glucoamylase-trapped hydrogel can be used with a BGM for portable and quantitative detection of cocaine and ATP (Yan et al., 2013). In this case, upon aptamer binding to ATP or cocaine, the hydrogel collapses to release glucoamylase, which catalyzes the hydrolysis of amylose to produce a large amount of glucose for quantitative readout by the BGM.

Besides aptamers, metal ion-dependent DNAzymes have also been successfully transformed into BGM-based sensors for highly selective quantification metal ions (Xiang and Lu, 2011, Fu et al., 2013, Xiang and Lu, 2013, Liao and Li, 2014, Zhang et al., 2015a). By introducing a DNA-conjugated invertase to the substrate of DNAzyme via hybridization, Xiang and co-workers developed a general methodology using BGMs to detect metal ions (Xiang and $\mathrm{Lu}, 2013$ ), including $\mathrm{Pb}^{2+}$ and $\mathrm{UO}_{2}{ }^{2+}$. In the presence of specific metal ions, the DNAzymes catalyze the hydrolysis reaction of their DNA substrates with an embedded ribonucleotide. The cleavage of the substrate into products weakens the hybridization between the substrate and the DNAzyme, resulting in release invertase-conjugated fragments, which can be used for glucose production followed by BGM quantification. Using this method, both $\mathrm{Pb}^{2+}$ and $\mathrm{UO}_{2}{ }^{2+}$ were successfully quantified by BGM with detection limits (16 $\mathrm{nM}$ and $5.0 \mathrm{nM}$ for $\mathrm{Pb}^{2+}$ and $\mathrm{UO}_{2}{ }^{2+}$, respectively) below the maximum contamination levels defined by the U.S. Environmental Protection Agency in drinking water (72 and $126 \mathrm{nM}$ for $\mathrm{Pb}^{2+}$ and $\mathrm{UO}_{2}{ }^{2+}$, respectively), and with excellent selectivity. The performance of these aptamer and DNAzyme based BGM sensors is summarized in Table 4.

Table 4. Performance of aptamer and DNAzyme based BGM sensors

\begin{tabular}{|c|c|c|c|c|c|}
\hline Target & LoD & Range & Assay time & Sample matrix & Reference \\
\hline \multicolumn{6}{|l|}{ Aptamer } \\
\hline \multirow[t]{4}{*}{ Cocaine } & $3.4 \mu \mathrm{M}$ & $3.4-500 \mu \mathrm{M}$ & $<15 \min$ & $\begin{array}{l}\text { Serum, } \\
\text { animal blood }\end{array}$ & Xiang and Lu, 2011 \\
\hline & $3.8 \mu \mathrm{M}$ & $3.8-750 \mu \mathrm{M}$ & $\sim 1 \mathrm{hr}$ & Urine & Yan et al., 2013 \\
\hline & N.P. & $<1 \mathrm{mM}$ & $\sim 6 \mathrm{hr}$ & Buffer & Hou et al., 2014 \\
\hline & $1.8 \mu \mathrm{M}$ & $1.8-800 \mu \mathrm{M}$ & N.P. & Buffer & Zhou et al., 2014b \\
\hline Adenosine & $18 \mu \mathrm{M}$ & $18-1000 \mu \mathrm{M}$ & $<30 \min$ & Buffer & Xiang and Lu, 2011 \\
\hline \multirow[t]{2}{*}{ ATP } & $8 \mu \mathrm{M}$ & $8 \mu \mathrm{M}-800 \mu \mathrm{M}$ & $\sim 6 \mathrm{hr}$ & Buffer & Hou et al.,2014 \\
\hline & N.P. & $<1 \mathrm{mM}$ & $\sim 1 \mathrm{hr}$ & Buffer & Yan et al., 2013 \\
\hline Dopamine & $0.08 \mu \mathrm{M}$ & $0.08-100 \mu \mathrm{M}$ & $\sim 4 \mathrm{~h}$ & Serum & Hun et al., 2015b \\
\hline Melamine & $0.53 \mu \mathrm{M}$ & $0-500 \mu \mathrm{M}$ & $\sim 30 \mathrm{~min}$ & Whole milk & Gu et al., 2015 \\
\hline Myoglobin & $50 \mathrm{pM}$ & $50 \mathrm{pM}-50 \mathrm{nM}$ & $\sim 2.5 \mathrm{hr}$ & Serum & Wang et al., 2015a \\
\hline PDGF-BB & $2.9 \mathrm{fM}$ & $10 \mathrm{fM}-3.16 \mathrm{pM}$ & $\sim 2 \mathrm{hr}$ & Saliva & Ma et al., 2014 \\
\hline $\mathrm{INF}-\gamma$ & $2.6 \mathrm{nM}$ & $2.6-400 \mathrm{nM}$ & $\sim 45 \mathrm{~min}$ & Serum & Xiang and Lu, 2011 \\
\hline
\end{tabular}




\begin{tabular}{|c|c|c|c|c|c|}
\hline \multicolumn{6}{|c|}{ DNAzyme } \\
\hline $\mathrm{UO}_{2}^{2+}$ & $9.1 \mathrm{nM}$ & $9.1-200 \mathrm{nM}$ & $\sim 1 \mathrm{hr}$ & Buffer & Xiang and Lu, 2011 \\
\hline \multirow{5}{*}{$\mathrm{Pb}^{2+}$} & $5 \mathrm{nM}$ & $5-1000 n M$ & $\sim 1.5 \mathrm{hr}$ & Buffer & Xiang and Lu, 2013 \\
\hline & $16 \mathrm{nM}$ & $16-1000 \mathrm{nM}$ & $\sim 1.5 \mathrm{hr}$ & Buffer & Xiang and Lu, 2013 \\
\hline & $1.0 \mathrm{pM}$ & $1.0 \mathrm{pM}-1 \mathrm{nM}$ & $\sim 40 \mathrm{~min}$ & Buffer & Fu et al., 2013 \\
\hline & $2.0 \mathrm{pM}$ & $5.0 \mathrm{pM}-500 \mathrm{pM}$ & N.P. & Buffer & Liao and Li, 2014 \\
\hline & $1.0 \mathrm{pM}$ & $1.0 \mathrm{pM}-0.8 \mathrm{nM}$ & $\sim 2.5 \mathrm{hr}$ & Pond water & Zhang et al., 2015a \\
\hline
\end{tabular}

\subsubsection{Employing nucleic Acid hybridization as target recognition elements in BGM-based IVDs}

Nucleic acids are biopolymers that encode genetic information through specific nucleotide base-pairing. The general strategy of using nucleic acids as recognition elements is based on sequence specific hybridization in which the target gene sequence is identified by a DNA/RNA probe that hybridizes the targeted nucleic acid sequence with high efficiency and extremely high specificity. This sequence-specific hybridization combined with enzymatic amplification using DNA or RNA polymerase is the basic principle of molecule diagnostics (MDx) (Sisk, 1997).

To employ the same principles of MDx onto BGM-based biosensors, a DNA and enzyme conjugate that is capable of hybridizing with target sequence was commonly used as a signaling probe to generate a detectable glucose signal (Xiang and Lu, 2012b, Xu et al., 2012, Xue-tao et al., 2014, Du et al., 2015, Xu et al., 2015). Xiang and co-workers reported the first BGM-based assay to quantify viral DNA fragment by using a DNA-invertase conjugate to hybridize and detect a viral DNA fragment captured on capture probe functionalized magnetic beads via sequence-specific hybridization. The capture of viral DNA fragment is detected in a sequence-specific manner and translated into a glucose signal (Figure 4) (Xiang and $\mathrm{Lu}, 2012 \mathrm{~b}$ ). A LoD of $40 \mathrm{pM}$ synthetic hepatitis B viral fragment was achieved but requires over $10 \mathrm{hr}$ for the assay. To further improve the sensitivity of the BGM based MDx assay, instead of conjugating one enzyme to one detection probe, a strategy reported by Xu el al. used $\mathrm{Fe}_{3} \mathrm{O}_{4} / \mathrm{Au}$ nanoparticle loaded with multiple signaling enzymes to improve the sensitivity of DNA detection down to $0.5 \mathrm{pM}$ with an assay time of about $2 \mathrm{hr}$ (Xu et al., 2012). 


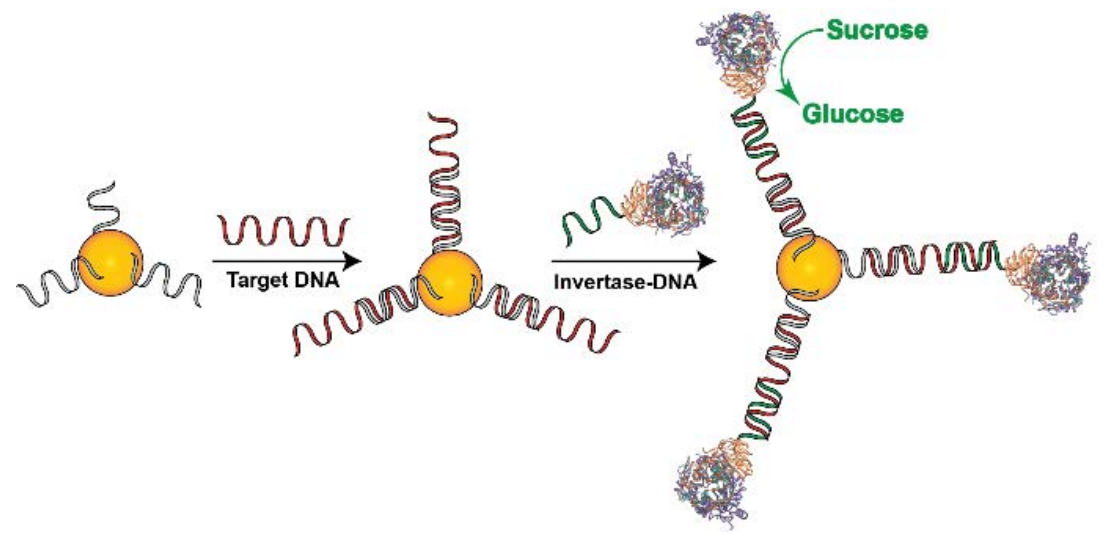

Figure 4. Quantification of DNA using BGM.

Alternative approaches to improving sensitivity employ different signal amplification methods such as isothermal circular strand-displacement polymerization reaction (Xu et al., 2015), exonuclease-III-assisted signal amplification (Xue-tao et al., 2014), and isothermal amplification with strand exchange circuits (Du et al., 2015). These systems are compatible with other electrochemical (Drummond et al., 2003) or optical DNA sensors (Sharon et al., 2010). To further expand the capability, Wang and co-workers have developed an integrated microfluidic chip with BGM-based DNA sensors to enable multiplex detection of three genotypes of hepatitis B virus DNA with a LoD of 10 pM (Wang et al., 2014a). Most notably, this work demonstrates the promise of BGM-based sensors for high-throughput DNA detection. In addition to the above DNA sensors, telomeric DNA, thymine (T)-containing oligonucleotides, and specific protein binding-DNA were also successfully transformed into BGM-based sensors for the selective and sensitive detection of telomerase activity in Hela cells (down to 80 cells $/ \mathrm{mL}$ ) (Wang et al., 2014b, Zhu et al., 2014), $\mathrm{Hg}^{2+}$ in environmental water sample ( $\mathrm{LoD}=8.0 \mathrm{nM}$ ) (Xue-tao et al., 2015) and transcription factors in embryonic stem cells ( $\mathrm{LoD}=0.4 \mathrm{ng} / \mathrm{mL}$ Oct4) (Chen et al., 2014) respectively.

\subsubsection{Employing direct enzyme recognition in BGM-based IVDs}

Enzymes have historically been the first recognition elements used in biosensors and continue to be the basis for a significant number of studies on biosensors in general, because of their commercial availability, ease of isolation and purification, high specificity of enzyme-substrate interaction and high catalytic rates (Chambers et al., 2008). Initially, quantification of ethanol, cholesterol and lactate have been reported using redox reactions catalyzed by alcohol dehydrogenase, cholesterol oxidase, and lactate dehydrogenase, respectively. The reactions generated currents that can be directly monitored by BGM without actually producing glucose (Figure 5A) (Nie et al., 2010). However, this approach requires the enzymatic reactions to generate an electrical signal that is directly detectable by the BGM as well as the production of customized strips to accommodate the individual enzyme reagents. To address these limitations, efforts have been made to synthesize the enzyme substrates that covalently link to glucose for releasing glucose in response to a target enzyme (Mohapatra and Phillips, 2013) (Figure 5b) as well as using the enzyme combination for detection of a upstream target analyte (Wang et al., 2015b, Zhang et al., 2015b). For instance, 
Yang and co-workers developed a sensitive one-step method for quantitative detection of $\alpha$-amylase (AMS) in serum and urine coupled with $\alpha$-glucosidase (Wang et al., 2015b). In this approach, the AMS present in sample hydrolyzes maltopentaose to release maltotriose and maltose, followed by $\alpha$-glucosidase catalyzed conversion of maltotriose and maltose into glucose. The AMS activity was measured using a one-step process with a LoD at $20 \mathrm{U} / \mathrm{L}$. Similarly, with the help of alkaline phosphatase, quantification of the activities of galactose-1-phosphate uridylyltransferase was recently demonstrated for galactosemia diagnosis in clinical samples (Zhang et al., 2015b). The contamination of E. coli in water can also be monitored by quantification of the $\beta$-galactosidase enzyme released by $E$. coli bacteria using a BGM (Chavali et al., 2014).

Without using customized test strips or special enzyme substrates, a more recent report has demonstrated the use of non-modified commercial BGM to quantitate enzymatic activity or metabolites via the direct detection of NADH (Zhang et al., 2016). In this report, Zhang et al. have discovered that some of the current BGM systems are capable of direct quantitation of $\mathrm{NADH}$, a natural coenzyme used in many enzymatic reactions. As a result, a large number of enzymatic reactions that consumes or generates NADH can be directly monitored using BGM. The authors demonstrate the quantitation of lactate, an important metabolite in blood, using the enzymatic reactions catalyzed by lactate dehydrogenase and lactate oxidase, which consumes NADH in a molar ratio to lactate present. In addition, determination of enzymatic

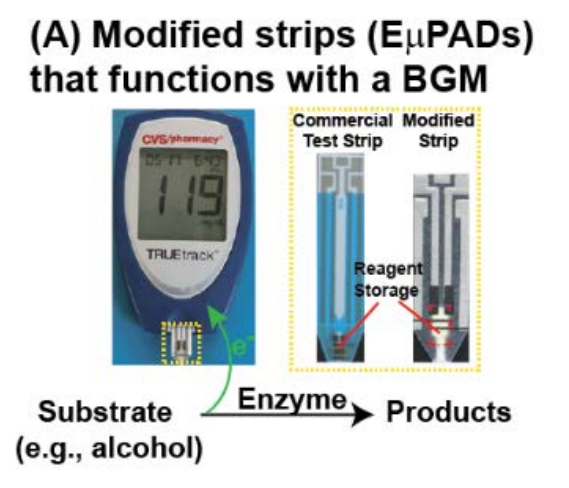

(C) Determination metabolite or enzymatic activity via direct NADH quantitation using BGM

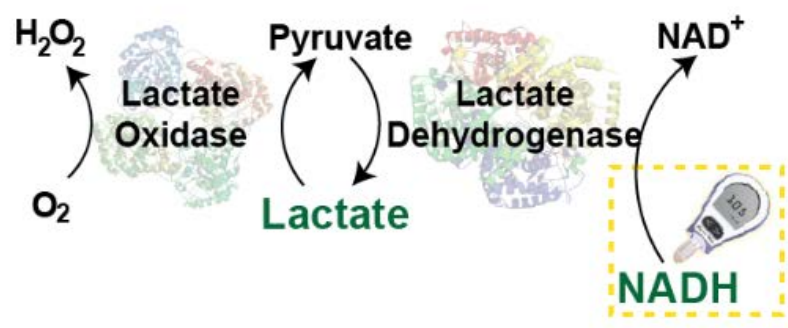

(B) Modified substrates for quantifying enzyme activity using BGM
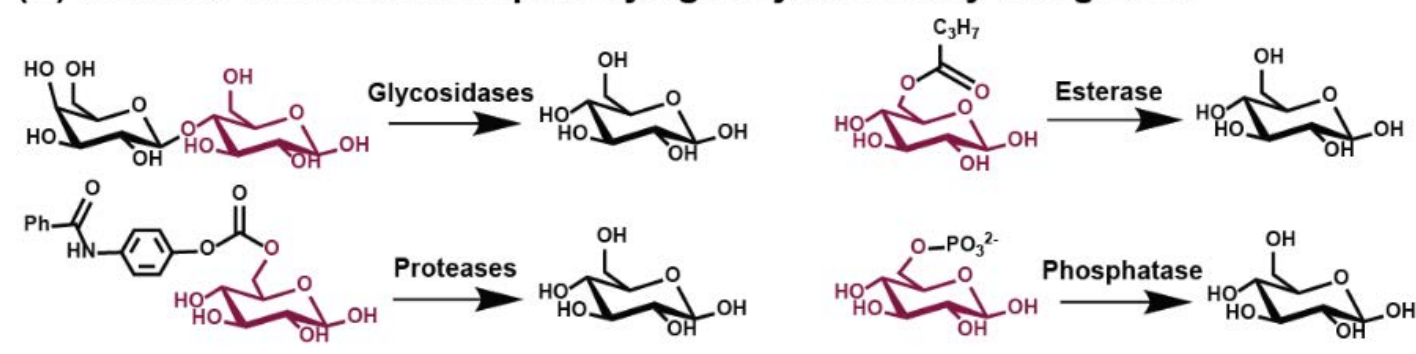

Figure 5. (A) E $\mu \mathrm{PAD}$ developed by Nie et al. that contains different enzymes at the carbon electrodes and directly generates an electrochemical signal $\left(\mathrm{e}^{-}\right)$when targets specific for the enzymes are present, such as lactate (with lactate dehydrogenase), cholesterol (with cholesterol oxidase), and alcohol (with alcohol dehydrogenase). Adopted from Nie et al. with permission from Royal Chemical Society; (B) Modified substrate with covalently attached glucose for determining enzymatic activity using unmodified BGM; (C) Determination of lactate level using enzymatic reactions and direct detection of NADH using BGM. 
activity of glucose-6-phosphate dehydrogenase (G6PD), which catalyzes the conversion of glucose-6-phosphate to 6-phosphoglucoolactone while generating $\mathrm{NADH}$ from $\mathrm{NAD}^{+}$, has also been demonstrated (Figure 5C).

\subsubsection{Other target recognition methods}

Although the majority of the BGM-based assays depend on antibody, aptamer, DNAzyme or enzyme for recognition, other target recognition methods have been reported. Molecular imprinting has been adopted for generating selective binding sites in synthetic polymers using molecular templates (Schirhagl, 2014). Molecularly imprinted polymers (MIPs) are economical and stable synthetic receptors with antibody-like binding properties that can provide specific recognition sites for a target molecule when the analyte is used as a template (Schirhagl, 2014). Moreover, magnetic MIPs (m-MIPs) achieve magnetic separation and simplify the pretreatment procedures. In one example, the determination of chloramphenicol (CAP) by a BGM was demonstrated using m-MIPs and a $\beta$-cyclodextrin- and invertase-functionalized signal tag, in which the m-MIPs were fabricated using polydopamine molecularly imprinted film modified $\mathrm{Fe}_{3} \mathrm{O}_{4}$ nanoparticles with 2,2-dichloroacetamide as a template that can capture the 2,2-dichloroacetamide segment of CAP (Chen et al., 2015). Although offering a great promise to synthesize a broad range of target receptors, current MIP has a limitation in recognizing larger size molecules, such as proteins, with high selectivity (Kryscio and Peppas, 2012). This difficulty is in part due to the non-physiological condition in which the MIP is synthesized, causing structural changes on the protein template and leading to an altered binding site (Kryscio et al., 2012b, a).

In addition to MIPs, a specific peptide was used as an enzyme substrate for quantification of protein biomarkers, including protein kinase (PK) (Yang et al., 2015) and prostate-specific antigen (PSA) (Hun et al., 2015a). Others have used inhibition or activation of chemical reactions, such as copper (I) catalyzed azide-alkyne cycloaddition reaction, for detection of histidine (Zhou et al., 2014a), and $\mathrm{Cu}^{2+}$ (Su et al., 2013), respectively, using a BGM. Finally, the specific interaction between bacterial and a quaternized magnetic nanoparticle has also been employed for sensitive detection of $E$. coli and $S$. aureus down to 20 cells $/ \mathrm{mL}$ (Wang et al., 2015c).

\section{Conclusion and Perspectives}

In conclusion, recent developments demonstrate the significant clinical utility and feasibility of using BGM for the quantification of a wide range of biomarkers in IVD and mobile health. The addition of IVD capabilities to today's mobile health devices will potentially enable cost-effective mass screening and evidence-based personalized healthcare and medicine that includes preventive healthcare, precision medicine, and immediate feedback. To achieve this goal, the current mobile healthcare system, especially the diagnostic component, should be made easy, intuitive, and lost cost, much like today's BGM.

For practical application, several issues associated with today's BGM system will need to be addressed. First, the BGM is designed for monitoring of the physiological level of blood glucose, which has a range between $10-600 \mathrm{mg} / \mathrm{dL}(0.56-33 \mathrm{mM})$. The time it requires for the enzymatic generation to reach this range can be long, especially for biomarkers present in very low quantity, such as low abundance proteins, viral DNA or RNA. As a result, for 
practical application, portable glucose sensors with lower working ranges should be developed (Sun et al., 2015, He et al., 2016). Second, the software on the BGM should be modified to directly display the target concentration instead of a glucose level. Third, since glucose is commonly present in biological levels in various amount, any BGM tests of non-glucose targets need to take the endogenous glucose into account. Currently, this issue has been addressed by using glucose strip to measure the background glucose immediately before the measurement of the non-glucose targets and then subtract the background glucose reading before the calculation of the non-glucose targets. The more straightforward way of accounting for the endogenous glucose is to either integrate the background subtraction step with the final measurement in a single disposable or employ enzymes, such as hexokinase to convert the background glucose into other molecules before the binding and signal transduction of the non-glucose targets, as demonstrated in a recent study (Zhang et al., 2016). Fourth, diagnostic test cartridges will need to develop to both incorporate the benefits of existing glucose test strips as well as optimal fluid handling to obtain a true POC or home use system (Chin et al., 2007, Ligler et al., 2007, Peter et al., 2008). Despite these issues, expanding the capability of today's BGM is a technically viable option to shift IVD tests from hospitals and centralized labs to the hands of patients.

\section{Acknowledgments}

The work in the Lu group and GlucoSentient described in this review has been financially supported by the National Science Foundation (IIP-1158781, IIP-1215421, and IIP-1330934) and National Institute of Health (1R43DK100213-01 and 1R43DA035524-01).

\section{Figure Legends}

Figure 2. Different approaches using BGMs for quantification of non-glucose targets.

Figure 2. Designs for BGM based immunoassays, in both the sandwich (A) and competitive (B) formats. (Xiang and Lu, 2012a).

Figure 3. The design of the first BGM based assay using aptamers and DNAzymes. (Xiang and $\mathrm{Lu}, 2011$ )

Figure 4. Quantification of DNA using BGM.

Figure 5. (A) E $\mu \mathrm{PAD}$ developed by Nie et al. that contains different enzymes at the carbon electrodes and directly generates an electrochemical signal $\left(\mathrm{e}^{-}\right)$when targets specific for the enzymes are present, such as lactate (with lactate dehydrogenase), cholesterol (with cholesterol oxidase), and alcohol (with alcohol dehydrogenase). Adopted from Nie et al. with permission from Royal Chemical Society; (B) Modified substrate with covalently attached 
glucose for determining enzymatic activity using unmodified BGM; (C) Determination of lactate level using enzymatic reactions and direct detection of NADH using BGM. 


\section{References:}

IBG Star, 510(k) substantial equivalence determination decision summary $(510(\mathrm{k})$ number: K103544).

Ali MM, et al. Developing fluorogenic RNA-cleaving DNAzymes for biosensing applications. Methods. Mol. Biol. 2012;848:395-418.

Bankar SB, et al. Glucose oxidase--an overview. Biotechnol. Adv. 2009;27:489-501.

Beaudry AA, Joyce GF. Directed evolution of an RNA enzyme. Science. 1992;257:635-41.

Belcarz A, et al. The novel non-glycosylated invertase from Candida utilis (the properties and the conditions of production and purification). Biochim. Biophys. Acta. 2002;1594:40-53.

Blaik RA, et al. Gold-coated M13 bacteriophage as a template for glucose oxidase biofuel cells with direct electron transfer. ACS Nano. 2016;10:324-32.

Boguslavsky LI, et al. Amperometric thin film biosensors based on glucose dehydrogenase and toluidine blue o as catalyst for NADH electrooxidation. Biosens. Bioelectron. 1995;10:693-704.

Breaker RR, et al. A DNA enzyme that cleaves RNA. Chem. Biol. 1994;1:223-9.

Brown AK, et al. A lead-dependent DNAzyme with a two-step mechanism. Biochemistry. 2003;42:7152-61.

Brown AK, et al. Biochemical characterization of a uranyl ion-specific DNAzyme. Chembiochem. 2009; 10:486-92.

Cardosi M, Liu Z. Amperometric glucose sensors for whole blood measurement based on dehydrogenase enzymes. In: Canuto RA, editor. Dehydrogenases: INTECH; 2012. p. 319-54.

Carmi N, et al. Cleaving DNA with DNA. Proc. Natl. Acad. Sci. USA. 1998;95:2233-7.

Carmi N, Breaker RR. Characterization of a DNA-cleaving deoxyribozyme. Bioorg. Med. Chem. 2001;9:2589-600.

Carmi N, et al. In vitro selection of self-cleaving DNAs. Chem. Biol. 1996;3:1039-46.

Cartier LJ, et al. Toxic levels of acetaminophen produce a major positive interference on Glucometer Elite and Accu-Chek advantage glucose meters. Clin. Chem. 1998;44:893-4.

Chambers JP, et al. Biosensor recognition elements. Curr. Issues. Mol. Biol. 2008;10:1-12.

Chavali R, et al. Detection of Escherichia coli in potable water using personal glucose meters. Anal. Methods. 2014;6:6223-7.

Chavez FP, et al. Purification and characterization of an invertase from Candida utilis: Comparison with natural and recombinant yeast invertases. J. Biotechnol. 1997;53:67-74.

Chen J, et al. A universal glucometer-based biosensor for portable and quantitative detection of transcription factors. Anal. Methods. 2014;6:4840.

Chen S, et al. A portable and antibody-free sandwich assay for determination of chloramphenicol in food based on a personal glucose meter. Anal. Bioanal. Chem. 2015;407:2499-507.

Chin CD, et al. Lab-on-a-chip devices for global health: past studies and future opportunities. Lap. Chip. 2007;7:41-57.

Cunningham DD. Blood glucose monitoring. In: Schreiner S, Bronzino JD, Peterson DR, editors. Medical instruments and devices: Principles and practices. Boca Raton, FL: CRC Press; 2016. p. 3.

Drummond TG, et al. Electrochemical DNA sensors. Nat. Biotechnol. 2003;21:1192-9.

Du Y, et al. A sweet spot for molecular diagnostics: Coupling isothermal amplification and strand exchange circuits to glucometers. Sci. Rep. 2015;5:11039.

Ellington AD, Szostak JW. In vitro selection of RNA molecules that bind specific ligands. Nature. 1990;346:818-22. 
Ellington AD, Szostak JW. Selection in vitro of single-stranded DNA molecules that fold into specific ligand-binding structures. Nature. 1992;355:850-2.

FDA. Advice for patients: Serious errors with certain blood glucose monitoring test strips. U.S. FDA2009.

FDA. Blood glucose monitoring test systems for prescription point-of-care use. Draft guidance for industry and food and drug administration staff 2014.

Felice AK, et al. Substrate specificity and interferences of a direct-electron-transfer-based glucose biosensor. J. Diabetes. Sci. Technol. 2013;7:669-77.

Ferri S, et al. Review of glucose oxidases and glucose dehydrogenases: A bird's eye view of glucose sensing enzymes. J. Diabetes. Sci. Technol. 2011;5:1068-76.

Forman DT, et al. Evaluation of a reagent strip-reflectance meter serum glucose method. Laboratory Medicine. 1972;3:26-9.

Fu L, et al. Portable and quantitative monitoring of heavy metal ions using DNAzyme-capped mesoporous silica nanoparticles with a glucometer readout. J. Mater. Chem. B. 2013;1:6123-8.

Fu X, et al. A portable and quantitative enzyme immunoassay of neuron-specific enolase with a glucometer readout. Anal. Methods. 2014;6:2233.

$\mathrm{Fu} \mathrm{X}$, et al. Glucoamylase-labeled nanogold flowers for in situ enhanced sensitivity of a glucometer-based enzyme immunoassay. Anal. Methods. 2015;7:507-12.

Gangadhara, et al. Influence of polyols on the stability and kinetic parameters of invertase from Candida utilis: Correlation with the conformational stability and activity. Protein J. 2008;27:440-9.

Gao Z, et al. Nanoparticle-based pseudo hapten for target-responsive cargo release from a magnetic mesoporous silica nanocontainer. Chem. Comm. 2014;50:6256-8.

Giri B, et al. Signal amplification strategies for microfluidic immunoassays. Trends Analyt. Chem.

$\mathrm{Gu} \mathrm{C}$, et al. Portable detection of melamine in milk using a personal glucose meter based on an in vitro selected structure-switching aptamer. Anal. Chem. 2015;87:7676-82.

Hall RH. Biosensor technologies for detecting microbiological foodborne hazards. Microbes. Infect. 2002;4:425-32.

$\mathrm{He} \mathrm{W}$, et al. Printing graphene-carbon nanotube-ionic liquid gel on graphene paper: Towards flexible electrodes with efficient loading of ptau alloy nanoparticles for electrochemical sensing of blood glucose. Analytica. chimica. acta. 2016;903:61-8.

Heller A, Feldman B. Electrochemical glucose sensors and their applications in diabetes management. Chem. Rev. 2008;108:2482-505.

Heller A, Feldman B. Electrochemistry in diabetes management. Acc. Chem. Res. 2010;43:963-73.

Hones J, et al. The technology behind glucose meters: test strips. Diabetes. Technol. Ther. 2008;10:S10-S26.

Hou L, et al. Bioresponsive controlled release from mesoporous silica nanocontainers with glucometer readout. Chem. Comm. 2014;50:1441-3.

Hun X, et al. Peptide-based biosensor for the prostate-specific antigen using magnetic particle-bound invertase and a personal glucose meter for readout. Microchim. Acta. 2015a;182:1669-75.

Hun X, et al. Aptamer biosensor for highly sensitive and selective detection of dopamine using ubiquitous personal glucose meters. Sens. Actuators, B: Chem. 2015b;209:596-601.

iBGSTAR. Ibgstar® blood glucose meter. Sanofi; 2011.

ISO. In vitro diagnostic test systems - requirements for blood-glucose monitoring systems for self-testing in managing diabetes mellitus. ISO 15197:2013.

Janssen W, et al. Positive interference of icodextrin metabolites in some enzymatic glucose methods. Clin. Chem. 1998;44:2379-80. 
Joo J, et al. A facile and sensitive method for detecting pathogenic bacteria using personal glucose meters. Sens. Actuators, B: Chem. 2013;188:1250-4.

Kryscio DR, et al. Conformational studies of common protein templates in macromolecularly imprinted polymers. Biomed. Microdevices. 2012a;14:679-87.

Kryscio DR, et al. Protein conformational studies for macromolecularly imprinted polymers. Macromol. Biosci. 2012b;12:1137-44.

Kryscio DR, Peppas NA. Critical review and perspective of macromolecularly imprinted polymers. Acta. Biomater. 2012;8:461-73.

Kulys J, et al. Probing aspergillus niger glucose oxidase with pentacyanoferrate(iii) aza- and thia-complexes. J. Inorg. Biochem. 2006;100:1614-22.

Kumar P, Satyanarayana T. Microbial glucoamylases: Characteristics and applications. Crit. Rev. Biotechnol. 2009;29:225-55.

Lan $\mathrm{T}$, et al. Detection of protein biomarker using a blood glucose meter. Methods. Mol. Biol. 2015;1256:99-109.

Lee SH, et al. Electrochemical study on screen-printed carbon electrodes with modification by iron nanoparticles in fe(cn)(6) (4-/3-) redox system. Anal. Bioanal. Chem. 2005;383:532-8.

$\mathrm{Li} \mathrm{J}$, et al. In vitro selection and characterization of a highly efficient $\mathrm{Zn}$ (ii)-dependent RNA-cleaving deoxyribozyme. Nucleic Acids Res. 2000;28:481-8.

Li Y, Lu Y. Functional nucleic acids for analytical applications: Springer-Verlag New York; 2009.

Liang B, et al. Study of direct electron transfer and enzyme activity of glucose oxidase on graphene surface. Electrochem. commun. 2015;50:1-5.

Liao J-Y, Li H. Target-induced DNAzyme cleavage accompanying bioactive enzymatic assembly with glucometer readout for quantitative monitoring of lead ion. Chem. Lett. 2014;43:1599-600.

Ligler FS, et al. The array biosensor: Portable, automated systems. Anal. Sci. 2007;23:5-10.

Liu H, et al. Aptamer-based origami paper analytical device for electrochemical detection of adenosine. Angew. Chem. Int. Ed. Engl. 2012;51:6925-8.

Liu J, et al. A catalytic beacon sensor for uranium with parts-per-trillion sensitivity and millionfold selectivity. Proc. Natl. Acad. Sci. USA. 2007;104:2056-61.

Liu J, et al. Functional nucleic acid sensors. Chem. Rev. 2009;109:1948-98.

Lu Y, Liu J. Functional DNA nanotechnology: Emerging applications of DNAzymes and aptamers. Curr. Opin. Biotechnol. 2006;17:580-8.

Ludwig R, et al. Cellobiose dehydrogenase modified electrodes: Advances by materials science and biochemical engineering. Anal. Bioanal. Chem. 2013;405:3637-58.

Ma X, et al. Aptamer-based portable biosensor for platelet-derived growth factor-bb (pdgf-bb) with personal glucose meter readout. Biosens. Bioelectron. 2014;55:412-6.

mHealth G. Device listing november 2012. A global list of commercially available devices in the healthcare sector, updated fortnightly. 2012.

Millan JL. Alkaline phosphatases : Structure, substrate specificity and functional relatedness to other members of a large superfamily of enzymes. Purinergic Signal. 2006;2:335-41.

Mohapatra H, Phillips ST. Reagents and assay strategies for quantifying active enzyme analytes using a personal glucose meter. Chem. Comm. 2013;49:6134-6.

Mok W, Li Y. Recent progress in nucleic acid aptamer-based biosensors and bioassays. Sensors. 2008;8:7050.

Morgan CL, et al. Immunosensors: Technology and opportunities in laboratory medicine. Clin. Chem. 1996;42:193-209. 
Morris NA, et al. An electrochemical capillary fill device for the analysis of glucose incorporating glucose oxidase and ruthenium (iii) hexamine as mediator. Electroanalysis. 1992;4:1-9.

Navani NK, Li Y. Nucleic acid aptamers and enzymes as sensors. Curr. Opin. Chem. Biol. 2006;10:272-81.

Nie Z, et al. Integration of paper-based microfluidic devices with commercial electrochemical readers. Lap. Chip. 2010;10:3163-9.

Nutiu R, Li Y. Structure-switching signaling aptamers. J. Am. Chem. Soc. 2003;125:4771-8.

Nutiu R, Li Y. Structure-switching signaling aptamers: Transducing molecular recognition into fluorescence signaling. Chemistry. 2004;10:1868-76.

Nutiu R, Li Y. In vitro selection of structure-switching signaling aptamers. Angew. Chem. Int. Ed. Engl. 2005;44:1061-5.

Peter BH, Jr., et al. A combinatorial approach to microfluidic mixing. J. Micromech Microeng. 2008;18:115019.

Ryabov AD. Transition metal chemistry of glucose oxidase, horseradish peroxidase, and related enzymes. Advances in inorganic chemistry: Academic Press; 2004. p. 201-69.

Sai Lau P, Li Y. Functional nucleic acids as molecular recognition elements for small organic and biological molecules. Curr. Org. Chem. 2011;15:557-75.

Santoro SW, Joyce GF. A general purpose RNA-cleaving DNA enzyme. Proc. Natl. Acad. Sci. USA. 1997;94:4262-6.

Santoro SW, Joyce GF. Mechanism and utility of an RNA-cleaving DNA enzyme. Biochemistry. 1998;37:13330-42.

Sato $\mathrm{A}$, et al. $\mathrm{Ca}(2+)$ stabilizes the semiquinone radical of pyrroloquinoline quinone. Biochem $\mathrm{J}$. 2001;357:893-8.

Sauer J, et al. Glucoamylase: Structure/function relationships, and protein engineering. Biochim. Biophys. Acta. 2000;1543:275-93.

Schirhagl R. Bioapplications for molecularly imprinted polymers. Anal. Chem. 2014;86:250-61.

Seehuber A, Dahint R. Conformation and activity of glucose oxidase on homogeneously coated and nanostructured surfaces. J Phys Chem B. 2013;117:6980-9.

Shangguan D, et al. Aptamers evolved from live cells as effective molecular probes for cancer study. Proc. Natl. Acad. Sci. USA. 2006;103:11838-43.

Sharon E, et al. CdSe/ZnS quantum dots-G-quadruplex/hemin hybrids as optical DNA sensors and aptasensors. Anal. Chem. 2010;82:7073-7.

Shen Z, et al. A catalytic DNA activated by a specific strain of bacterial pathogen. Angew. Chem. Int. Ed. Engl. 2015.

Shriver-Lake LC, et al. Antibody immobilization using heterobifunctional crosslinkers. Biosens. Bioelectron. 1997;12:1101-6.

Sisk RB. Quantitative and diagnostic pcr in the analysis of gene expression. New York, NY: Springer Science-Business Media; 1997.

Smith JE, et al. Optimization of antibody-conjugated magnetic nanoparticles for target preconcentration and immunoassays. Anal. Biochem. 2011;410:124-32.

$\mathrm{Su}$ J, et al. Personal glucose sensor for point-of-care early cancer diagnosis. Chem. Comm. 2012;48:6909-11.

$\mathrm{Su}$ J, et al. Sensitive detection of copper(ii) by a commercial glucometer using click chemistry. Biosens. Bioelectron. 2013;45:219-22.

Sun Y, et al. Real-time electrochemical detection of hydrogen peroxide secretion in live cells by pt nanoparticles decorated graphene-carbon nanotube hybrid paper electrode. Biosens. Bioelectron. 2015;68:358-64.

Tang D, et al. Low-cost and highly sensitive immunosensing platform for aflatoxins using one-step competitive 
displacement reaction mode and portable glucometer-based detection. Anal. Chem. 2014;86:11451-8.

Tang Z, et al. Effects of drugs on glucose measurements with handheld glucose meters and a portable glucose analyzer. Am J Clin Pathol. 2000;113:75-86.

Telcare. Telcare. 2013.

Tellechea E, et al. Engineering the interface between glucose oxidase and nanoparticles. Langmuir. 2012;28:5190-200.

Terse-Thakoor T, et al. Electrochemically functionalized seamless three-dimensional graphene-carbon nanotube hybrid for direct electron transfer of glucose oxidase and bioelectrocatalysis. Langmuir. 2015;31:13054-61.

Tonyushkina K, Nichols JH. Glucose meters: A review of technical challenges to obtaining accurate results. J. Diabetes. Sci. Technol. 2009;3:971-80.

Torabi S-F, Lu Y. Functional DNA nanomaterials for sensing and imaging in living cells. Curr. Opin. Biotechnol. 2014;28:88-95.

Torabi SF, et al. In vitro selection of a sodium-specific DNAzyme and its application in intracellular sensing. Proc. Natl. Acad. Sci. USA. 2015;112:5903-8.

Tsujimura S, et al. Novel FAD-dependent glucose dehydrogenase for a dioxygen-insensitive glucose biosensor. Biosci. Biotechnol. Biochem. 2006;70:654-9.

Tuerk C, Gold L. Systematic evolution of ligands by exponential enrichment: Rna ligands to bacteriophage t4 DNA polymerase. Science. 1990;249:505-10.

Uematsu K, et al. Promotion effect by epsilon-poly-1-lysine on the enzymatic reaction of glucose oxidase with ferricyanide ion as an oxidant. Anal. Sci. 2012;28:657-60.

Wang Q, et al. Sensitive point-of-care monitoring of cardiac biomarker myoglobin using aptamer and ubiquitous personal glucose meter. Biosens. Bioelectron. 2015a;64:161-4.

Wang Q, et al. Multiplex detection of nucleic acids using a low cost microfluidic chip and a personal glucose meter at the point-of-care. Chem. Comm. 2014a;50:3824-6.

Wang Q, et al. A sensitive one-step method for quantitative detection of alpha-amylase in serum and urine using a personal glucose meter. Analyst. 2015b;140:1161-5.

Wang Y, et al. Wrapping DNA-gated mesoporous silica nanoparticles for quantitative monitoring of telomerase activity with glucometer readout. J. Mater. Chem. B. 2014b;2:5847-53.

Wang Z, et al. Transmutation of personal glucose meters into portable and highly sensitive microbial pathogen detection platform. Small. 2015c:DOI: 10.1002/smll.201500944.

Willner B, et al. Electrical contacting of redox proteins by nanotechnological means. Curr. Opin. Biotechnol. 2006; 17:589-96.

Wong DW. Food enzymes: Structure and mechanism. New York, NY: Chapman \& Hall; 1995.

$\mathrm{Wu} \mathrm{C}$, et al. A general excimer signaling approach for aptamer sensors. Biosens. Bioelectron. 2010;25:2232-7.

$\mathrm{Wu} \mathrm{S}$, et al. Biofunctionalized dendritic polyaniline nanofiber for in situ amplified glucometer-based enzyme immunoassay of tumor marker. Anal. Methods. 2015;7:1843-8.

Xiang Y, et al. Using the widely available blood glucose meter to monitor insulin and hbalc. J. Diabetes. Sci. Technol. 2014;8:855-8.

Xiang Y, Lu Y. Using personal glucose meters and functional DNA sensors to quantify a variety of analytical targets. Nat. Chem. 2011;3:697-703.

Xiang Y, Lu Y. Portable and quantitative detection of protein biomarkers and small molecular toxins using antibodies and ubiquitous personal glucose meters. Anal. Chem. 2012a;84:4174-8.

Xiang Y, Lu Y. Using commercially available personal glucose meters for portable quantification of DNA. Anal. Chem. 2012b;84:1975-80. 
Xiang Y, Lu Y. An invasive DNA approach toward a general method for portable quantification of metal ions using a personal glucose meter. Chem. Comm. 2013;49:585-7.

Xiang Y, Lu Y. DNA as sensors and imaging agents for metal ions. Inorg. Chem. 2014;53:1925-42.

$\mathrm{Xu} \mathrm{J}$, et al. Sensitive point-of-care monitoring of hiv related DNA sequences with a personal glucometer. Chem. Comm. 2012;48:10733-5.

$\mathrm{Xu} \mathrm{XT}$, et al. Portable and sensitive quantitative detection of DNA based on personal glucose meters and isothermal circular strand-displacement polymerization reaction. Biosens. Bioelectron. 2015;64:671-5.

Xue-tao X, et al. Portable and sensitive quantitative detection of DNA using personal glucose meters and exonuclease iii-assisted signal amplification. Analyst. 2014;139:4982-6.

Xue-tao X, et al. Highly sensitive and portable mercury(ii) ion sensor using personal glucose meter. Anal. Methods. 2015;7:81-5.

Yan L, et al. Target-responsive "sweet" hydrogel with glucometer readout for portable and quantitative detection of non-glucose targets. J. Am. Chem. Soc. 2013;135:3748-51.

Yang W, et al. Portable and sensitive detection of protein kinase activity by using commercial personal glucose meter. Sens. Actuators, B: Chem. 2015;210:508-12.

Yoo EH, Lee SY. Glucose biosensors: An overview of use in clinical practice. Sensors (Basel). 2010;10:4558-76.

Zhang J, et al. Low-cost and highly efficient DNA biosensor for heavy metal ion using specific DNAzyme-modified microplate and portable glucometer-based detection mode. Biosens. Bioelectron. 2015a;68:232-8.

Zhang J, et al. Using a personal glucose meter and alkaline phosphatase for point-of-care quantification of galactose-1-phosphate uridyltransferase in clinical galactosemia diagnosis. Chem. Asian. J. 2015b;10:2221-7.

Zhang J, et al. Dose-dependent response of personal glucose meters to nicotinamide coenzymes: Applications to point-of-care diagnostics of many non-glucose targets in a single step. Angew. Chem. Int. Ed. Engl. 2016;55:732-6.

Zhang L, et al. A polyaniline microtube platform for direct electron transfer of glucose oxidase and biosensing applications. J. Mater. Chem. B. 2015c;3:1116-24.

Zhang X-B, et al. Metal ion sensors based on DNAzymes and related DNA molecules. Annu. Rev. Anal. Chem. 2011;4.

Zhao L, et al. Portable and quantitative evaluation of stem cell therapy towards damaged hepatocytes. RSC Adv. 2015a;5:19439-44.

Zhao Y, et al. Glucose encapsulating liposome for signal amplification for quantitative detection of biomarkers with glucometer readout. Biosens. Bioelectron. 2015b;72:348-54.

Zhou J, et al. A portable chemical sensor for histidine based on the strategy of click chemistry. Biosens. Bioelectron. 2014a;51:386-90.

Zhou X, et al. Interfacial electron transfer of glucose oxidase on poly(glutamic acid)-modified glassy carbon electrode and glucose sensing. Anal. Biochem. 2015;489:9-16.

Zhou Z, et al. Simple and efficient method to purify DNA-protein conjugates and its sensing applications. Anal. Chem. 2014b;86:3869-75.

Zhu X, et al. Sensitive and portable detection of telomerase activity in hela cells using the personal glucose meter. Chem. Comm. 2014;50:7897-9. 